a hormone with an opposite effect on sugar metabolism to that of insulin, and that it is the absence of this hormone in the 'Houssay animal' which accounts for the lack of glycosuria when the pancreas is removed. Many other chapters in the complex story of endocrine interactions have been worked out in Prof. Houssay's laboratory and he has recently dealt with the problem of renal hypertension and the nature of the toxic substance which may be liberated by a diseased kidney. $\mathrm{He}$ is an honorary member of the Physiological Society and has published various papers in the Journal of Physiology.

\section{Prof. T. J. Jehu : Retirement from Chair of Geology at Edinburgh}

IN his student days T. J. Jehu, who is retiring from the regius chair of geology and mineralogy in the University of Edinburgh, had an unusually varied and distinguished career : at Edinburgh he graduated M.B., C.M. (1893), and B.Sc., with the class medal in geology (1894); at Cambridge he took a first class in both parts of the Natural Science Tripos (1897, 1898 ) and second class in the Moral Science Tripos (1899). Later, Jehu became lecturer in St. Andrews (1903-14), during which time he served on the Royal Commission on Coast Erosion (1906). In 1914 he returned to Edinburgh as professor of geology ; and it was during his tenure of office that the Grant Institute of Geology was founded and endowed.

Jehu's scientific papers have always been of unusual interest, and have mostly appoared in the Transactions of the Royal Society of Edinburgh. Until he left St. Andrews, the lakes and glaciation of Wales specially attracted his attention. He sounded the lakes of Snowdonia, and he investigated the interaction of the local and Irish Sea ice in both Pembrokeshire and Carnarvonshire. In 1917 he published a memoir with Robert Campbell on "The Highland Border Rocks of the Aberfoyle District", making an outstanding contribution to our knowledge of the Cambro-Ordovician sequence of the south-east margin of the Scottish Highlands, especially in regard to its palæontology. In 1922 he produced "The Archæan and Torridonian Formations and Later Intrusive Igneous Rocks of Iona". This publication is important in itself, but is now chiefly remembered as a prelude to the "Geology of the Outer Hebrides", which Jehu and R. M. Craig brought out in five parts between 1923 and 1934. It is not too much to say that this serial chronicled the greatest bit of field geology tackled by any British university during the present century. Its outstanding characteristic is its treatment of a belt of flinty crush rock found along the eastern shores of the Western Isles. Here, of course, Jehu and Craig share credit with J. W. Dougal; but plenty remains to ensure for Prof. Jehu in his retirement the warm gratitude of fellow workers in Scottish geology.

\section{Prof. Arthur Holmes, F.R.S. ; Appointed to Chair of Geology at Edinburgh}

Prof. Arthur Holmes, of the University of Durham, who succeeds Prof. Jehu as regius professor of geology in the University of Edinburgh, has an international reputation in the fields of petrology and geophysics. His name became closely linked with the classic pioneer work on radioactive minerals while he was still a junior member of staff at the Imperial College, South Kensington. He applied this new kind of quantitative data to a re-assessment of the age of the earth, and deduced the approximate period of time spanned by each of the geological ages in sequence-from Pre-Cambrian time to the present day. His contribution to both descriptive and interpretative petrology is voluminous and impressive. His later work incorporates many thought-compelling reviews of conventional hypotheses concerning the thermal history of the earth, the physical state of the earth's interior, the nature and variability of magma, and the origin of igneous rocks. His contributions to geology have profoundly influenced the scope and trend of contemporary work in the field of petrogenesis, and in close co-operation with Dr. Doris L. Reynolds he has in recent years amassed data demonstrating the effectiveness of alkalimetasomatism, transfusion by emanations from deepseated sources, and granitization-as processes transcending in importance those accommodated within the framework of enventional petrogenetic theory.

\section{U.S. National Academy of Sciences First Charles L. Mayer Award}

Prof. Charles B. Hugains, professor of surgery in the University of Chicago, has been awarded a two thousand dollar prize given by Dr. Charles L. Mayer and administered by the National Science Fund of the U.S. National Academy of Seiences. The award was offered for the "most outstanding contribution made during 1942 to present-day knowledge of factors affecting the growth of animal cells with particular reference to human cancer, and as a new type of prize for the advancement of fundamental scientific research administered under a new type of philanthropic foundation". The award was made to Prof. Huggins for his studies of the human prostate, with special relation to the cancers taking origin from this gland. He has shown that certain hormones which regulate the normal activities of prostatic cells have a marked influence as well on many of the cancers that are derived from them. By the utilization of this knowledge he has been enabled to control the growth of the cancers and of such secondary tumours as may already have formed in distant organs. These discoveries have large theoretical as well as practical implications.

A second Charles L. Mayer award of two thousand dollars for an outstanding study made in the same field in 1943 will be given, and entries and recommendations for consideration for this award should reach the office of the National Science Fund, 515 Madison Avenue, New York City, by January 15, 1944. The Advisory Committee is interested primarily in fundamental studies on the factors influencing growth of animal cells rather than applications to any particular aspect of normal or abnormal growth.

\section{Visual Aids to Education}

A SMALL exhibition of visual aids to education was held in the Conference Room of the Board of Education on May 25 and 26. This was organized for the Conference of Ministers of Education of Allied Governments meeting under the chairmanship of Mr. R. A. Butler, president of the Board of Education. The Board has already published a pamphlet dealing with mechanical visual aids. Here the problem was reviewed from a wider angle. The blackboard is the fundamental instrument of visual teaching. The problem of improving illustrated text-books is acute 
- the standard is very low. Meanwhile, until films are made to the requirements of teachers, really educational films are hard to get. The position of the sound-film is particularly difficult-facetious commentaries and lack of precise facts are obvious. Many teachers are turning from the film to other aids; of these the strip-film is the most important. In addition to the demonstration of class-room and background exhibitions, the need for making visual material available to the schools was stressed. Much useful material is available in museums, and teachers must be helped and guided in its use. The question of recording all exhibitions in booklet form is important. The Warburg Institute has done valuable work in this direction by means of photographs. Now the Army Bureau of Current Affairs, the Navy and many public bodies are arranging exhibitions, which contain material, facts and ideas of great educational use. Some central organization is needed to preserve this valuable work for educational purposes.

\section{Place of Psychology in the Sciences}

AdDressing a colloquium of the University of Manchester Branch of the Association of Scientific Workers on May 5, Prof. T. H. Pear explained why in psychology the traditional methods of science are sometimes inadequate. Science has sometimes been defined as measurement and sometimes as organized knowledge of facts, but not all facts can be measured. Moreover, if by facts be meant only events which are in principle open to observation by everyone who wishes to observe them, the psychologist has to study many phenomena, for example, mental images and colour experiences, which are not facts in this sense. Some would claim that they are therefore not amenable to the methods of science, but nevertheless they exist and are important; synæsthesia, for example. Physics has succeeded in maintaining a rigorous scientific method by ignoring certain difficult aspects of experience.

Prof. Pear said that there are few 'inner' inhibitions against analysing or manipulating inanimate matter ; more against studying the workings of the human body, and still more against intimate investigation of the mind. He urged the study of individuals side by side with the search for general laws. If this is not to be called science, scientific men should remember that in the case of human beings it may often be the more important study. $\mathrm{He}$ concluded by suggesting that the motives of the economist, the politician, of even the man of science, are subjects which interest the social psychologist.

\section{Light and Vision}

Aт a meeting of the Illuminating Engineering Society following the annual general meeting on May 11, Sir John Parsons gave an address on "Light and Vision". In his opening remarks Sir John recalled his presence at the inaugural dinner of the Society in 1909 , and the recognition of the founder of the Society, Mr. Leon Gaster, that its aims were not limited to physical problems, but involved physiological, psychological and æsthetic factors. At that time there was little guidance on lighting matters from the medical side, but engineers had themselves little data, and instruments for measuring illumination were primitive and cumbersome. The first paper read to the Society on glare in 1910 was given by himself, and the Society has since been preoccupied with this and similar problems involving vision. Sir John then discussed the relation between illumination and visual acuity, directing attention to the valuable work of Dr. Lythgoe and others and the development of the Illuminating Engineering Society's Code. Research has established the great importance of background and adequate contrast. The work of Dr. Stiles and others on glare (for which we have no actual physiological test), the effects of specular reflection from polished material and the inconvenience and occasional danger of harsh shadows-most difficult, however, to define with precision-were dealt with. Turning to the colour of light Sir John expressed the view that there is no evidence that artificial sources furnishing so-called 'white light' cause any harmful effects. The injurious effects of ultra-violet light in everyday life have been grossly exaggerated and the craze for 'daylight' lamps has been unwarranted.

Much of the later part of the address was devoted to vision at low illuminations, the peculiar appearance of colours in weak light and the conditions determining the perception of objects at the very low illuminations which are now experienced in the streets in war-time. Reference was made to the work of the Departmental Committee on Lighting in Factories and Workshops, and to the fact that legislation on factory lighting, recommended before the War of 1914-18, has only become a fact during the present War. Sir John referred to the value of the Illumin. ating Engineering Society Code and the recent researches on this subject by $\mathrm{Mr}$. $\mathrm{H}$. C. Weston, in which an effort has been made to give a scientific background without greatly disturbing the present set of values, which have become standard. The fact that requirements for adequate lighting in factories had now been incorporated in the Factory Act should serve as a precedent for the future, when lighting conditions in schools, offices, etc., might likewise be defined and standardized. The recognition of the I.E.S. Code during the War has been largely due to the fact that it was ready when needed. Now, therefore, is the time to complete codes and specifications relating to other fields of lighting.

\section{Protection of Structures Against Lightning}

J. F. SHIPLey, in a paper read in London before the Institution of Electrical Engineers on May 6, points out that the British Standards Institution has recently issued recommendations on this subject which constitute the first authoritative general guidance made available to the public in Great Britain since the Report of the Lightning Rod Conference in 1881 and its amendment by the Lightning Research Committee in 1905 . These new recommendations have been adopted by the Ministry of Works and Planning as its first code of practice, the latter containing additional appendixes in which comment is made on some of the new features dealt with, and which the present paper amplifies to some extent. The paper is confined to problems connected with the protection of modern steel-framed and ferroconcrete structures. The need for protection is discussed and a rough attempt is made to assess the lightning risk attached to any structure in any part of the world. The zone of protection receives attention and the presence of metallic systems in the buildings is mentioned; while the needs of structures which are very vulnerable to lightning, and of others which present difficult problems, are discussed. The components of a lightning protective system, their 